\title{
Aminated $\beta$-Cyclodextrin-Modified-Carboxylated Magnetic Cobalt/Nanocellulose Composite for Tumor-Targeted Gene Delivery
}

\author{
Thayyath Sreenivasan Anirudhan and Sylaja Raveendran Rejeena \\ Department of Chemistry, University of Kerala, Kariavattom, Trivandrum 695 581, India \\ Correspondence should be addressed to Thayyath Sreenivasan Anirudhan; tsani@rediffmail.com
}

Received 18 August 2014; Accepted 6 December 2014; Published 31 December 2014

Academic Editor: Rassoul Dinarvand

Copyright (C) 2014 T. S. Anirudhan and S. R. Rejeena. This is an open access article distributed under the Creative Commons Attribution License, which permits unrestricted use, distribution, and reproduction in any medium, provided the original work is properly cited.

\begin{abstract}
Gene therapy is a new kind of medicine, which uses genes as drugs in order to treat life threatening diseases. In the present work, a nonviral vector, aminated $\beta$-cyclodextrin-modified-carboxylated magnetic cobalt/nanocellulose composite (ACDC-Co/NCC), was synthesized for efficient transfection of genes into tumour cells. The synthesized ACDC-Co/NCC was characterized by means of FTIR, XRD, SEM, and ESR techniques. DNA condensing ability of ACDC-Co/NCC was found to be increased with increase in amount of ACDC-Co/NCC and $84.9 \%$ of DNA $(1.0 \mu \mathrm{g} / \mathrm{mL})$ inclusion was observed with $6.0 \mu \mathrm{g} / \mathrm{mL}$ of ACDC-Co/NCC. The cytotoxicity of ACDC-Co/NCC was observed to be minimal, even at higher concentration, with respect to the model transfecting agent, poly(ethyleneimine) (PEI). 88.2\% of the gene was transfected at high dose of DNA, as indicated by the highest luciferase expression. These results indicated that ACDC-Co/NCC might be a promising candidate for gene delivery with the characteristics of good biocompatibility, potential biodegradability, minimal cytotoxicity, and relatively high gene transfection efficiency.
\end{abstract}

\section{Introduction}

Gene delivery, the incorporation of foreign DNA particles into the host cells, is considered as one of the major objectives in the development of nucleic acid therapeutics. Gene therapy is a suitable substitute for conventional protein therapy because the problems such as bioavailability, systemic toxicity, manufacturing cost, and in vivo clearance rate can be solved [1]. It offers the opportunities and potential to cure both genetic and acquired diseases, such as hemophilia, cystic fibrosis, and cancers [2]. Previous experiments have confirmed that, at the molecular level, cancer is due to defects in the cellular DNA. The molecular pathogenesis of human cancer is due to structural and/or functional alterations of specific genes whose normal function is to control cell birth and cell death [3].

Gene delivery can be mediated by viral and nonviral methods. In viral methods, viruses deliver genetic materials to the specific disease sites via their efficient inherent mechanism. Viral vectors can provide efficient transduction and high gene expression. However, the use of viral vectors is quite limited due to safety concerns such as production of immunogenic reactions or mutagenesis of transfected cells [4]. These have necessitated the design of nonviral vectors as potential alternative which produces less complexity.

Nonviral vectors are attractive gene delivery systems for tumour gene therapy [5]. These have low immunogenicity, are easier to manufacture, have no signs of oncogenicity, and are relatively cheap compared to viral vectors [6]. In the past decade, a number of nonviral vectors such as cationic polymers (polyplexes), dendrimers, chitosans, liposomes, or cyclodextrins have been widely used in gene therapy [7-11]. Cyclodextrins (CDs) are cyclic $\alpha-(1,4-)$ linked oligosaccharides of $\alpha$-D-glucopyranose and have been extensively used as carriers to improve the solubility, stability, and bioavailability of chemical drugs, due to their low toxicity, lack of immunogenicity, biocompatibility, and ability to form inclusion complexes with a variety of guest molecules in solution and solid state [12]. $\beta$-CD is the most commonly used $C D$ in pharmaceutical formulations and has been extensively studied in 
human [6]. Many authors have used CD as an efficient carrier for gene transfection [13]. The formation of inclusion complex is not fixed and the interaction is highly favorable as it reduces the ring strain leading to a more stable lower energy state [14].

Using magnetic nanoparticles to enhance gene transfection, a recently developed technique termed magnetofection has been shown to be a powerful technology in gene delivery [15]. In this method, the complexes of nucleic acids and their vectors are combined with magnetic nanoparticles, so they can be drawn and concentrated to the target cells by applying a magnetic field. In addition to facilitating targeted gene delivery, the rapid sedimentation of the gene-particle complex onto the target area significantly reduces both the time and dose of the vector to achieve efficient transfection [16]. Magnetofection was found to be less cytotoxic than standard transfection. While searching for suitable elements for the magnetic core, transition metals like $\mathrm{Fe}, \mathrm{Ni}, \mathrm{Co}$, and $\mathrm{Mn}$ were found to be good candidates since they show high magnetization values which is important for high performance MRI and hyperthermia applications [17]. Magnetic hyperthermia, a thermal treatment of cancerous cells based on the fact that the cancer cells are more susceptible to high temperatures than the healthy ones, is regarded as a complementary technique to chemo- and radiotherapy as increasing the effects of these therapies and the MNPs can be used as heating mediators. In hyperthermia application, Co, being a hard magnetic material, is doped to other ferrites $\left(\mathrm{MFe}_{2} \mathrm{O}_{4}\right)$ in changing concentrations in order to increase the magnetic anisotropy eventually to improve the heat transfer rate.

The coating of magnetic core materials prevents the leaching of potentially toxic components into the body during in vivo applications. Coating of magnetic nanoparticles with natural polymers such as carbohydrates and proteins is common $[18,19]$, among which carbohydrates are particularly popular owing to their biocompatibility. Moreover, functionalization is possible by making use of the hydroxyl groups on the carbohydrate skeletons [20]. Nanocellulose (NC) is an attractive biotemplate material for the fabrication of nanostructures. This NC has been used widely as stabilizing matrix for the metal nanoparticles and the developed composites have been used in various biomedical applications, such as antimicrobial wound dressing [21, 22]. The inclusion of metallic nanoparticles can be achieved in the NC matrix, by the treatment of metallic salts with reducing agents (e.g., $\left.\mathrm{NaBH}_{4}\right)[23]$.

The airway and alveolar epithelium are the sites where genetic disorders such as cystic fibrosis or inherited surfactant protein B deficiency and lung cancer have major fatal impacts. Hence, the respiratory system has been considered as an attractive target for gene therapy intervention, in addition to its large surface area and accessibility [24, 25]. Several authors have used magnetofection to transfect a number of cell types including primary lung epithelial cells [26] and blood vessel endothelial cells [27].

Given these premises, the aim of the present work was to develop a novel nonviral gene vector, aminated $\beta$-cyclodextrin-modified-carboxylated magnetic cobalt/nanocellulose composite (ACDC-Co/NCC), with improved transfection efficiency to epithelial cells. Magnetofection may be effective for targets close to the body's surface (epithelial cells), as the magnetic field strength falls off rapidly with distance [28]. $\beta$ $\mathrm{CD}$ has the merit of a hydrophobic cavity which is easy to assemble with genes. The grafting of $\mathrm{CD}$ molecules onto the magnetic cobalt nanoparticles/nanocellulose matrix may lead to a molecular carrier that possess the cumulative effects of inclusion, size specificity, and transport properties of CD and the site specificity of Co nanoparticles to target cells by applying a magnetic field, commonly called "magnetofection." Triethylenetetramine (TETA) has large number of positive sites or secondary amine groups which will easily condense the negatively charged genes to form polyplexes [29]. Moreover, the positive charge of TETA is highly desirable for effective cell transfection as cell membranes are negatively charged. Effective gene delivery depends on its stability and ability to transfect across the cell membrane and interferes with the host DNA. So, the systematic investigations on the formation of polymer/DNA complexes, gene transfection ability, and cell viability were evaluated in alveolar epithelial cells (A549 cell line).

\section{Experimental}

2.1. Materials. Nanocellulose crystals were extracted from the sawdust of Mangifera indica, collected from local sawmill, Trivandrum. Cobalt chloride hexahydrate $\left(M_{W}: 129.84 \mathrm{~g} / \mathrm{mol}\right)$ is obtained from SD Fine-Chem Ltd. (Mumbai, India). The plasmid pCMVLuc (VR-1216) encoding Luciferase (Clontech, Palo, Alto, CA, USA) was used for carrying out the transfection experiments. Luciferase activity assay kit and protein assay kit were obtained from Promega (Madison, USA) and Bio-Rad Labs (Hercules, USA), respectively. Ethidium bromide (EtBr), 2,2,6,6-tetramethyl-1-(piperidinyloxy) radical (TEMPO), TETA, triethylamine (TEA), and $\beta$-CD $\left(M_{W}: 1135 \mathrm{~g} / \mathrm{mol}\right)$ were obtained from Sigma-Aldrich, Milwaukee, WI, USA. Sodium borohydride $\left(\mathrm{NaBH}_{4}\right), \mathrm{H}_{2} \mathrm{O}_{2}$, sulfuric acid, sodium hydroxide, $\mathrm{NH}_{4} \mathrm{OH}, \mathrm{NaClO}, \mathrm{NaBr}$, $\mathrm{NaHCO}_{3}$, p-toluenesulfonyl chloride, acetonitrile, 1-ethyl3-(3-dimethylaminopropyl) carbodiimide (EDC), and $\mathrm{HCl}$ were purchased from E-Merck (Worli, Mumbai, India) and used without further purification. Distilled water was used throughout the study.

2.2. Preparation of ACDC-Co/NCC. The synthesis of ACDC$\mathrm{Co} / \mathrm{NCC}$ involves the following steps, as demonstrated in Figure 1.

2.2.1. Extraction of Nanocellulose from Sawdust. The synthesis of nanocellulose was done following the procedure as already reported in our previous literature [30]. Briefly, sawdust was pretreated with $10 \% \mathrm{H}_{2} \mathrm{SO}_{4}$ solution $\left(120^{\circ} \mathrm{C}, 10 \mathrm{~min}\right)$ and centrifuged to remove rich pentosans solution. Delignification was achieved by the subsequent treatment with $1 \% \mathrm{NaOH}$ $\left(100^{\circ} \mathrm{C}, 1 \mathrm{~h}\right)$. The obtained brown mass was bleached with $5 \%$ $\mathrm{H}_{2} \mathrm{O}_{2}\left(80^{\circ} \mathrm{C}, 1 \mathrm{~h}\right)$ yielded white cellulose as the product [31]. About $5 \mathrm{~g}$ of the extracted cellulose was dispersed in $250 \mathrm{~mL}$ distilled water under magnetic stirring (20 min). $140 \mathrm{~mL} 98 \%$ 

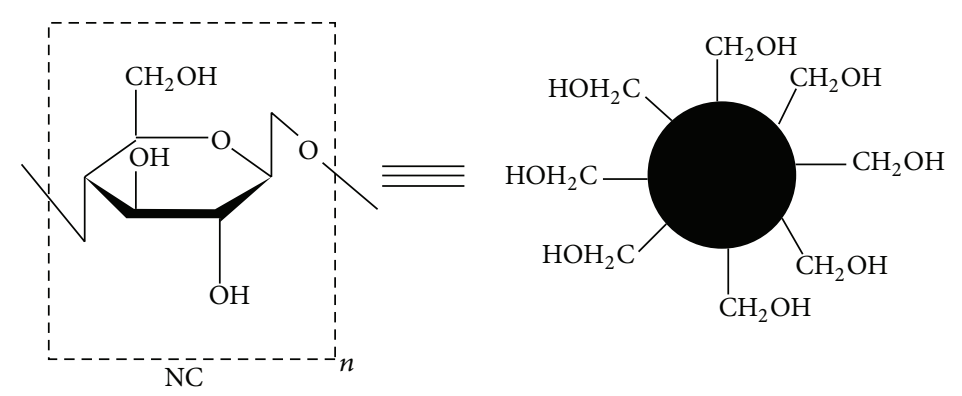

$\stackrel{\mathrm{CoCl}_{2} \cdot 6 \mathrm{H}_{2} \mathrm{O}, \mathrm{NaBH}_{4}}{\longrightarrow}$
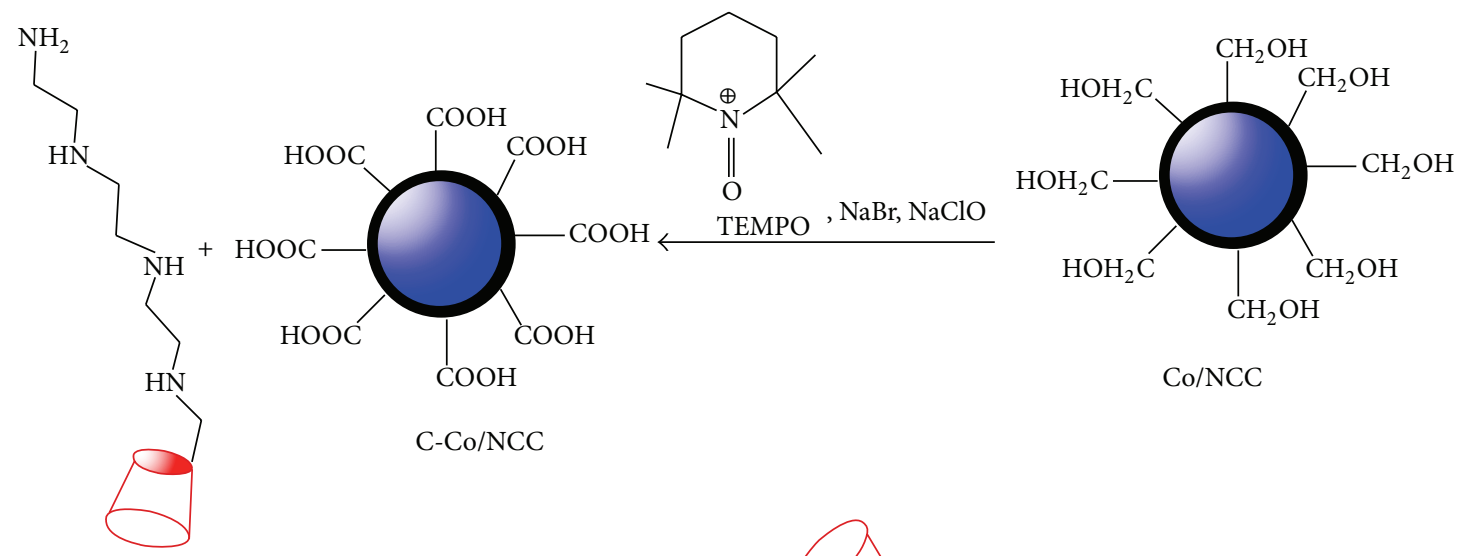

$\mathrm{Co} / \mathrm{NCC}$

ACD

C-Co/NCC

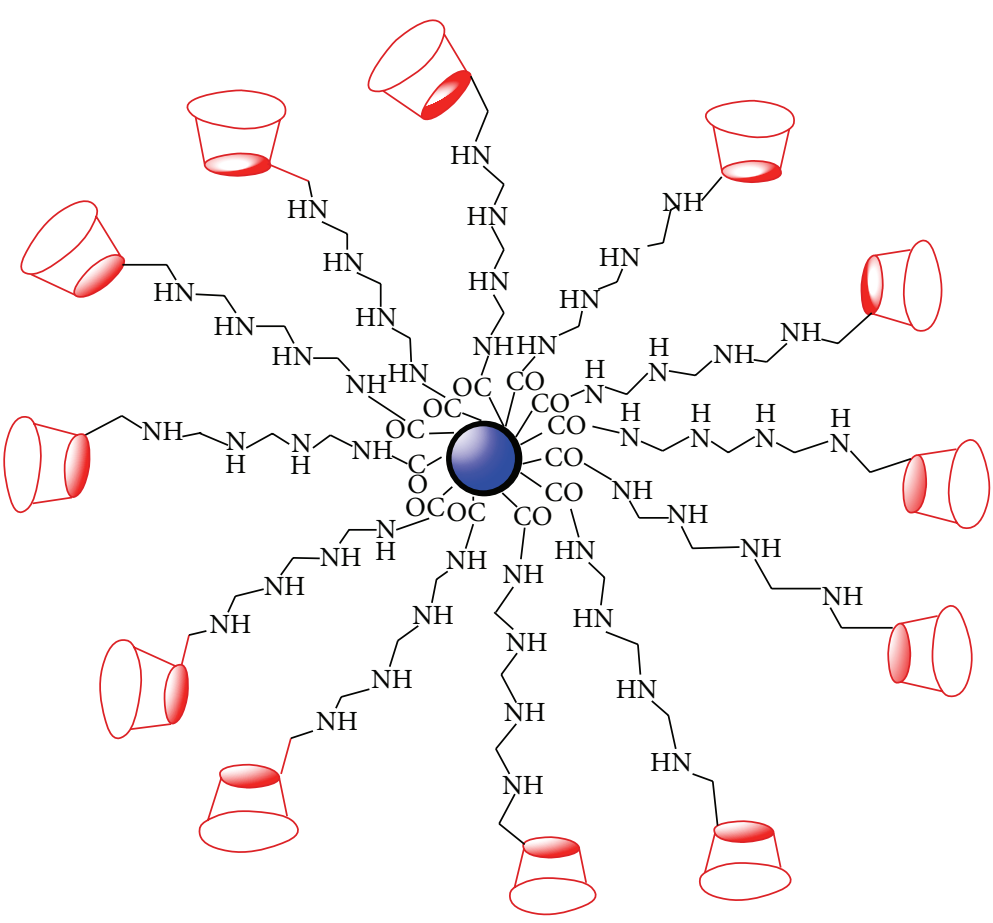

ACDC-Co/NCC

FIGURE 1: Predicted mechanism for the synthesis of the gene carrier, ACDC-Co/NCC.

sulfuric acid was dropped to the homogenized mixture, without causing heating. After complete addition, the mixture was heated at $50^{\circ} \mathrm{C}$ for $2 \mathrm{~h}$. The hot mixture was diluted ten times with ice cooled distilled water. The obtained white colloid was centrifuged, washed many times with water, and freeze-dried [32].
2.2.2. Synthesis of Co/NCC. The nanocomposite of Co and $\mathrm{NC}$ was prepared via chemical precipitation method. Diffusion of $\mathrm{Co}^{2+}$ into the nanocellulose matrix was carried out

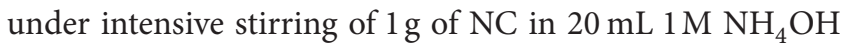
and $2 \mathrm{~mL} 0.1 \mathrm{M}$ of $\mathrm{CoCl}_{2} \cdot 6 \mathrm{H}_{2} \mathrm{O}$ solution for $1 \mathrm{~h}$ at $25^{\circ} \mathrm{C}$ and $\mathrm{pH}$ value of 12 . To the obtained suspension, we added $20 \mathrm{~mL}$ 
solution of $0.30 \mathrm{M} \mathrm{NaBH}_{4}$ and stirred intensively for $1 \mathrm{~h}$ at $50^{\circ} \mathrm{C}$.

\subsubsection{Preparation of Carboxylated Co/NCC (C-Co/NCC).} Nanocellulose was carboxylated according to the procedure by Araki et al. [33], as follows. $5.0 \mathrm{~g} \mathrm{NC}$ was suspended in $500 \mathrm{~mL}$ distilled water, to which $0.5 \mathrm{~g}$ of TEMPO and $5.0 \mathrm{~g}$ of $\mathrm{NaBr}$ were added. We added $\mathrm{NaClO}$ solution $(2.0 \mathrm{~mL})$ and the mixture was stirred for $4 \mathrm{~h}$ at room temperature with the $\mathrm{pH}$ adjusted to $10-11$ by $3 \mathrm{~N} \mathrm{NaOH}$. The obtained carboxylated magnetic nanocrystals were collected by the addition of $\sim 30 \mathrm{~g}$ of $\mathrm{NaCl}$ and $0.1 \mathrm{~N} \mathrm{HCl}$ and finally dialyzed against deionized water.

2.2.4. Preparation of Tosyl CD (TCD). Mono-6-deoxy-6-(ptoluenesulfonyl)-CD (TCD) was synthesized [34] as discussed below. $\beta$-CD $(20 \mathrm{~g}, 16.3 \mathrm{mmol})$ was suspended in $150 \mathrm{~mL}$ of water, and $\mathrm{NaOH}(2.16 \mathrm{~g}, 54.7 \mathrm{mmol})$ in $7 \mathrm{~mL}$ of water was added dropwise for $6 \mathrm{~min}$. The suspension became homogeneous and slightly yellow before the addition was complete. p-Toluenesulfonyl chloride $(3.36 \mathrm{~g}, 17.6 \mathrm{mmol})$ in $10 \mathrm{~mL}$ of acetonitrile was added dropwise over $8 \mathrm{~min}$, causing immediate formation of a white precipitate. After $2 \mathrm{~h}$ of stirring at room temperature, the precipitate was removed by filtration and cooled overnight at $4^{\circ} \mathrm{C}$.

2.2.5. Preparation of Aminated $C D$ ( $A C D)$. ACD was prepared via the reaction of TCD with TETA [35]. Briefly, TETA $(0.8 \mathrm{~g})$ and TCD $(4.0 \mathrm{~g})$ were dissolved in water $(30 \mathrm{~mL})$ containing TEA $(20 \mathrm{~mL})$, and the stirred mixture was heated to reflux under nitrogen atmosphere for $24 \mathrm{~h}$. After evaporation under reduced pressure, the residue was poured into the vigorously stirred anhydrous ethanol $(500 \mathrm{~mL})$, and the resultant mixture was filtered, washed, and freeze-dried to obtain a slight yellow precipitate.

2.2.6. Preparation of $A C D C-C o / N C C$. The gene carrier, ACDC-Co/NCC, was prepared using the procedure, as follows [36]. About $0.085 \mathrm{~g}(0.40 \mathrm{mmol})$ of the $\mathrm{C}-\mathrm{Co} / \mathrm{NCC}$ and $0.567 \mathrm{~g}(0.50 \mathrm{mmol})$ of the ACD were stirred in $3 \mathrm{~mL}$ water for $1 \mathrm{~h} .1 \mathrm{~mL}$ of EDC solution $(0.52 \mathrm{mmol}, 10 \%)$ was added to the reaction mixture and was stirred for $48 \mathrm{~h}$. The $\mathrm{pH}$ of the solution was adjusted to 2.0 by the addition of $\mathrm{HCl}$ and the solution was dialyzed against distilled water for 5 days. The obtained product was freeze-dried.

2.3. Estimation of Carboxyl Groups. Boehm titration was performed to determine the amount of free carboxyl ($\mathrm{COOH}$ ) groups. Briefly, about $0.15 \mathrm{~g}$ of powdered C-Co/NCC was shaken with $30 \mathrm{~mL} \mathrm{NaHCO}_{3}$ for $20 \mathrm{~h}$ and filtered. An aliquot of the filtrate was mixed with excess of $0.05 \mathrm{M} \mathrm{HCl}$ and the $\mathrm{CO}_{2}$ gas formed was boiled off and back titrated with $0.05 \mathrm{M} \mathrm{NaOH}$ [37]. The amount of carboxylic acid groups was estimated using the equation:

$$
\mathrm{COOH}(\mathrm{meq} / \mathrm{g})=\frac{\left(C_{\mathrm{NaOH}} \times V_{\mathrm{NaOH}}-C_{\mathrm{HCl}} \times V_{\mathrm{HCl}}\right)}{W},
$$

where $C$ is the concentration of $\mathrm{HCl}$ or $\mathrm{NaOH}(\mathrm{M}), W$ is the weight of the C-Co/NCC $(\mathrm{g})$, and $V$ is the volume of $\mathrm{HCl}$ or $\mathrm{NaOH}$ solution used $(\mathrm{mL})$.

2.4. DNA Binding Studies. High DNA condensing ability is an important factor for a successful polymeric gene delivery system [38]. Here the inclusion of DNA in the hydrophobic cavity of the $\mathrm{CD}$ in the ACDC-Co/NCC was carried out as follows. The polymeric material, ACDC-Co/NCC, and DNA plasmid solution (in PBS buffer) were mixed in equivalent medium. The mixture was vortexed and then stayed at ambient conditions for $30 \mathrm{~min}$ before use. The DNA condensing abilities of ACDC-Co/NCC were measured using ethidium bromide (EtBr) assay. Briefly, $\mathrm{EtBr}(153 \mu \mathrm{L}$ of a $0.01 \%$ solution) was added to $96 \mu \mathrm{g}$ of DNA and diluted to $6 \mathrm{~mL}$. Desired concentrations of ACDC-Co/NCC were added to each well of a 96-well microplate, respectively, and $50 \mu \mathrm{L}$ of the DNA-EtBr solution was added to obtain a final volume of $100 \mu \mathrm{L}$. After incubation for $5 \mathrm{~min}$, the complexes were treated with $100 \mu \mathrm{L}$ of distilled water. The fluorescence was measured using HITACHI F-7000 fluorescence spectrophotometer. The $\lambda_{\text {ex }}$ and $\lambda_{\text {em }}$ were set at $526 \mathrm{~nm}$ and $592 \mathrm{~nm}$, respectively, as they are characteristic of DNA. Decrease in fluorescence intensity would result in higher inclusion \% due to the unavailability of DNA to ethidium bromide. The inclusion \% of DNA in the cyclodextrins was calculated using the formula:

$$
\begin{aligned}
& \text { inclusion } \% \\
& \begin{aligned}
= & {\left[1-\frac{\text { Concentration of DNA measured by fluoresence }}{\text { Practical concentration of DNA }}\right] } \\
& \times 100 .
\end{aligned}
\end{aligned}
$$

2.5. MTT Cytotoxicity Assay. The cytotoxicity or cell viability was evaluated by MTT assay using A549 cell (adenocarcinomic human alveolar basal epithelial cell line). Briefly, A549 cells were cultured in Dulbecco's modified Eagle's medium (DMEM) supplemented with $10 \%$ foetal bovine serum and 100 units/mL of penicillin/streptomycin at $37^{\circ} \mathrm{C}$ in a humidified atmosphere $\left(5 \% \mathrm{CO}_{2} / 95 \% \mathrm{O}_{2}\right)$. The cells were seeded into each well of a 96 -well plate $\left(10^{4}\right.$ cells/well). After $24 \mathrm{~h}$, the ACDC-Co/NCC complexes were prepared in culture medium and the media in the wells were replaced with the $200 \mu \mathrm{L}$ culture medium-sample mixture (equal to $1 \mu \mathrm{g}$ DNA). The plates were placed in an incubator and allowed to attach overnight. After incubation, culture medium and $20 \mu \mathrm{L}$ of MTT (3-(4,5-dimethylthiazol-2)-2,5-diphenyltetrazolium bromide) solution were used to replace the mixture in each well and incubated for further $4 \mathrm{~h}$ in $5 \% \mathrm{CO}_{2}$ at $37^{\circ} \mathrm{C}$. Then the culture medium and MTT were removed. The developed purple colored formazan crystals were dissolved in DMSO and analyzed by measuring absorbance at $570 \mathrm{~nm}$ in a colorimeter. The quantity of formazan crystals is directly proportional to the number of live cells. Cells incubated with pure media without treatment were considered as controls and the cell viability values were set as $100 \%$. For comparing the cell viability, the widely used transfecting agents such 
as PEI and its complex with DNA were considered, after following the cytotoxicity assay procedure. The cell viability (\%) was calculated according to the following equation:

$$
\text { Cell viability }(\%)=\frac{A_{\text {Sample }}-A_{\text {Blank }}}{A_{\text {Control }}-A_{\text {Blank }}},
$$

where $A_{\text {Sample }}$ and $A_{\text {Control }}$ represent absorption from the cells treated with the polymer complexes and $A_{\text {Blank }}$ represented absorption from the cells not treated with MTT.

\subsection{In Vitro Gene Transfection and Gene Expression Experi-} ments. The DNA transfection efficiency of ACDC-Co/NCC in vitro was evaluated using A549 cell lines following the procedure, reported earlier. Briefly, cells were separately seeded at a density of $10^{4}$ cells/well in a 96-well plate in $500 \mathrm{~mL}$ DMEM medium containing $10 \%$ foetal bovine serum (FBS) and incubated for $18 \mathrm{~h}$ before transfection. The medium was replaced with $400 \mathrm{~mL}$ fresh serum-free DMEM containing complexes with $1 \mathrm{mg}$ DNA. After incubation for $4 \mathrm{~h}$ at $37^{\circ} \mathrm{C}$, the transfection medium was replaced with fresh growth medium and then the cells were incubated for an additional $48 \mathrm{~h}$.

Luciferase activity was measured according to standard protocols of luciferase assay system. The total protein was measured according to a BCA protein assay kit (Pierce) and transfection efficiency was reported in terms of luciferase activity.

\section{Results and Discussion}

3.1. Gene Carrier-Preparation and Properties. The preparation of the gene carrier involves six steps, as described in the Experimental section. At first, cellulose was extracted from the value added product, sawdust, by acid-alkali treatment followed by bleaching with $\mathrm{H}_{2} \mathrm{O}_{2}$. Sawdust basically contains cellulose, lignin, and polyoses. The treatment of sawdust with $\mathrm{H}_{2} \mathrm{SO}_{4}(10 \%)$ and $\mathrm{NaOH}(1 \%)$ removed the polyoses and lignin, respectively. The obtained brown mass when bleached with $5 \% \mathrm{H}_{2} \mathrm{O}_{2}$ yielded a white cellulose powder. This cellulose powder was made into nanocrystals via acid hydrolysis which improves its crystallinity and hydrophilicity and it looks like a white pasty material. Since NC occupies a large number of hydroxyl groups, its swelling capacity would be high, and this property can be exploited for the production of biocompatible materials.

The Co/NCC prepared via chemical precipitation method appears like a flesh colored precipitate, where $\mathrm{Co}^{2+}$ ions get encapsulated in the NC matrix. The surface coating ensures a double-sided isolation both preventing the release of toxic cobalt ions from magnetic core into the biological media and shielding the magnetic core from oxidization and corrosion. The surface coating molecules such as antibodies, peptides, and polysaccharides permit specific recognition of cell types and target the nanoparticles to a specific tissue or cell type by binding to a cell surface receptor. Even though Co is a highly toxic metal when compared to the commonly used Fe, it is reported that it can be successfully utilized for in vivo applications after proper encapsulation. During in vivo applications once the magnetic nanoparticles (MNPs) are injected into the body, they are recognized by the body's major defence system, which eliminates any foreign substance from blood stream. However, the specific surface coatings elongate the MNPs circulation time in blood and maximize the possibility to reach target tissues [17].

The Co/NCC was carboxylated using TEMPO where the primary hydroxyl groups in the nanocellulose were converted to carboxyl groups. The amount of carboxyl groups in the $\mathrm{C}$ $\mathrm{Co} / \mathrm{NCC}$ was estimated to be $2.23 \mathrm{meq} \mathrm{g}^{-1}$. The gene carrier, ACDC-Co/NCC, was prepared by the amidification reaction between $\mathrm{C}-\mathrm{Co} / \mathrm{NCC}$ and aminated cyclodextrin (ACD) using EDC. EDC forms an unstable intermediate complex with carboxylic groups, which is susceptible to amide bond formation if it reacts with a primary amine. The yield of ACDC-Co/NCC was found to be $68.6 \%$. The long chain in the ACDC-Co/NCC arises from TETA, increases the flexibility to capture the DNA molecules, and helps in their condensation owing to large amount of amino groups in the chain.

\subsection{Characterization Studies}

3.2.1. FTIR Spectra. Figure 2 presents the FTIR spectra of the cellulose, NC, Co/NCC, C-Co/NCC, and ACDC-Co/NCC. The IR spectra of cellulose show the characteristic broad peak related to hydrogen bonded $\mathrm{O}-\mathrm{H}$ stretching vibration at $3441 \mathrm{~cm}^{-1}$ and the peak at 2922 and $1033 \mathrm{~cm}^{-1}$ could be attributed to the $\mathrm{C}-\mathrm{H}$ stretching and $\mathrm{C}-\mathrm{H}$ bending of the $\mathrm{CH}_{2}$ group. In 1636 and $668 \mathrm{~cm}^{-1}$, there are signals corresponding to the $\mathrm{C}=\mathrm{O}$ stretching of hemicelluloses and $\beta$-glycosidic linkage in cellulose, respectively. The band at $897 \mathrm{~cm}^{-1}$ is characteristic of glycosidic ring in cellulose structure. NC shows all the characteristic peaks of cellulose and the position may somehow change due to the breaking of intermolecular hydrogen bonding between the cellulose chains. The absorption band at $607 \mathrm{~cm}^{-1}$ in $\mathrm{Co} / \mathrm{NCC}$ is associated with the metal-O stretching vibration which confirms the presence of Co nanoparticles. The C-Co/NCC shows a new sharp adsorption peak at $1729 \mathrm{~cm}^{-1}$, a characteristic of an ester carbonyl group. The absorption at $1391 \mathrm{~cm}^{-1}$ in ACDC$\mathrm{Co} / \mathrm{NCC}$ is attributed to the in-plane bending vibrations of hydroxy groups, which may arise from large number of cyclodextrin molecules. Meanwhile, the asymmetrical and symmetrical stretchings of methylene $\left(-\mathrm{CH}_{2}-\right)$ appear at 2919 and $2853 \mathrm{~cm}^{-1}$, and the in-plane bending of $\mathrm{CH}_{2}$ is located at about $1462 \mathrm{~cm}^{-1}$. In addition, the new band at $1056 \mathrm{~cm}^{-1}$ is responsible for the stretching vibration of $\mathrm{C}-\mathrm{O}$. The presence of peaks at the vibration frequencies, $1646 \mathrm{~cm}^{-1}(\mathrm{C}=\mathrm{O}$ stretch), $1554 \mathrm{~cm}^{-1}$ (amide linkage), and $1407 \mathrm{~cm}^{-1}$ (primary amides), also confirms the functionalization onto ACDCCo/NCC.

3.2.2. XRD Analysis. The XRD patterns of cellulose, NC, $\mathrm{Co} / \mathrm{NCC}$, and ACDC-Co/NCC are shown in Figure 3. In the XRD pattern of cellulose, the diffraction maxima at $2 \theta=$ $5.8,22.1$, and $34.2^{\circ}$ can be attributed to the partial crystalline nature of cellulose-like natural polymers [39]. The characteristic peaks of NC are the same as that of cellulose; however, its broadness increased to a small extent which indicates 


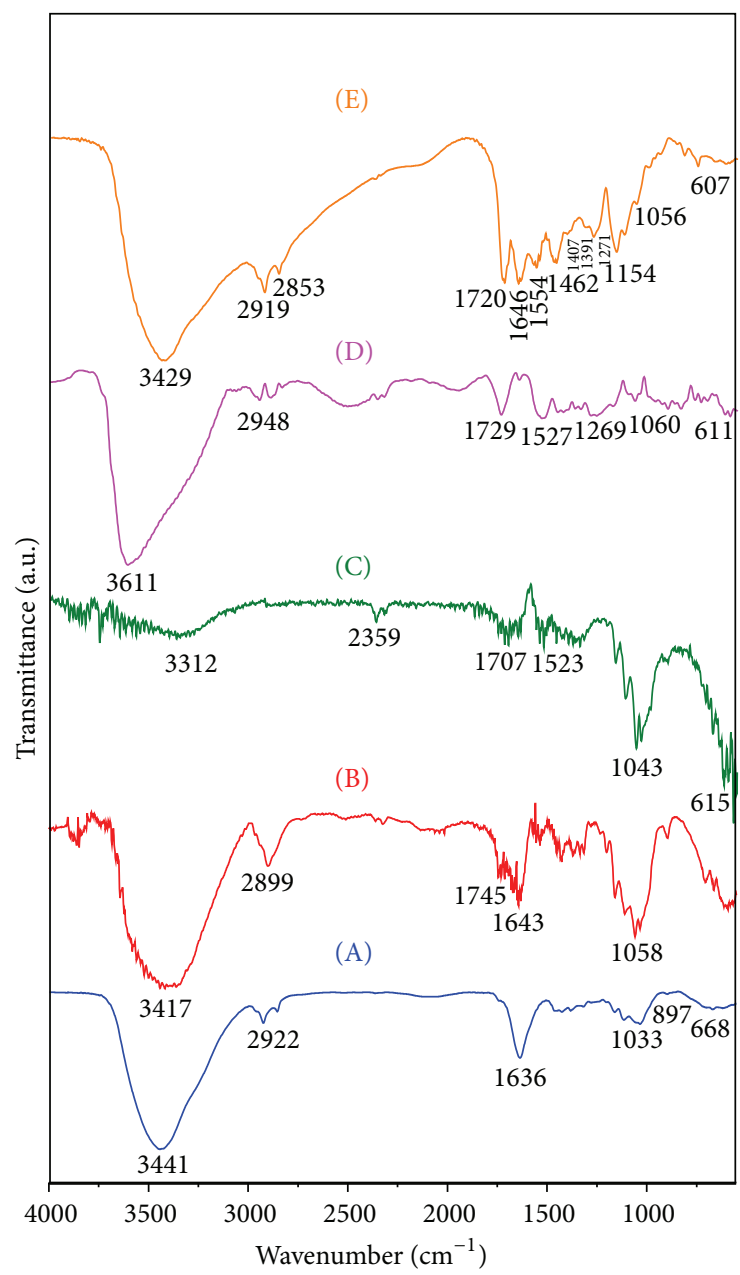

Figure 2: FTIR spectra of (A) Cellulose, (B) NC, (C) Co/NCC, (D) $\mathrm{C}-\mathrm{Co} / \mathrm{NCC}$, and (E) ACDC-Co/NCC.

the reduced particle size. The sharper diffraction peaks are indication of a high degree of crystallinity in the structure, which arises due to the partial removal of the amorphous regions during the acid hydrolysis treatment of cellulose [40]. The percentage crystallinity of cellulose and NC was compared using the equation [41]:

$$
\text { Crystallinity }(\%)=\frac{\left(I_{c}-I_{a}\right)}{I_{c}} \times 100,
$$

where $I_{c}$ and $I_{a}$ are the intensity of the crystalline and amorphous peaks, respectively. The percentage crystallinity of cellulose and NC, using this equation, was $67.05 \%$ and $81.74 \%$, respectively. The high percentage crystallinity of NC as compared to cellulose may be due to the endoglucanase mediated hydrolysis during their preparation.

The average crystallite size of $\mathrm{NC}$ and $\mathrm{Co} / \mathrm{NCC}$ calculated by fitting Lorentzian and using Debye-Scherrer formula [42] was 21.6 and $19.2 \mathrm{~nm}$, respectively. The shifting of characteristic peaks of cellulose in $\mathrm{Co} / \mathrm{NCC}$ suggests the presence of dopant in the matrix. The increased amorphous nature and disappearance of characteristic peaks in diffraction pattern

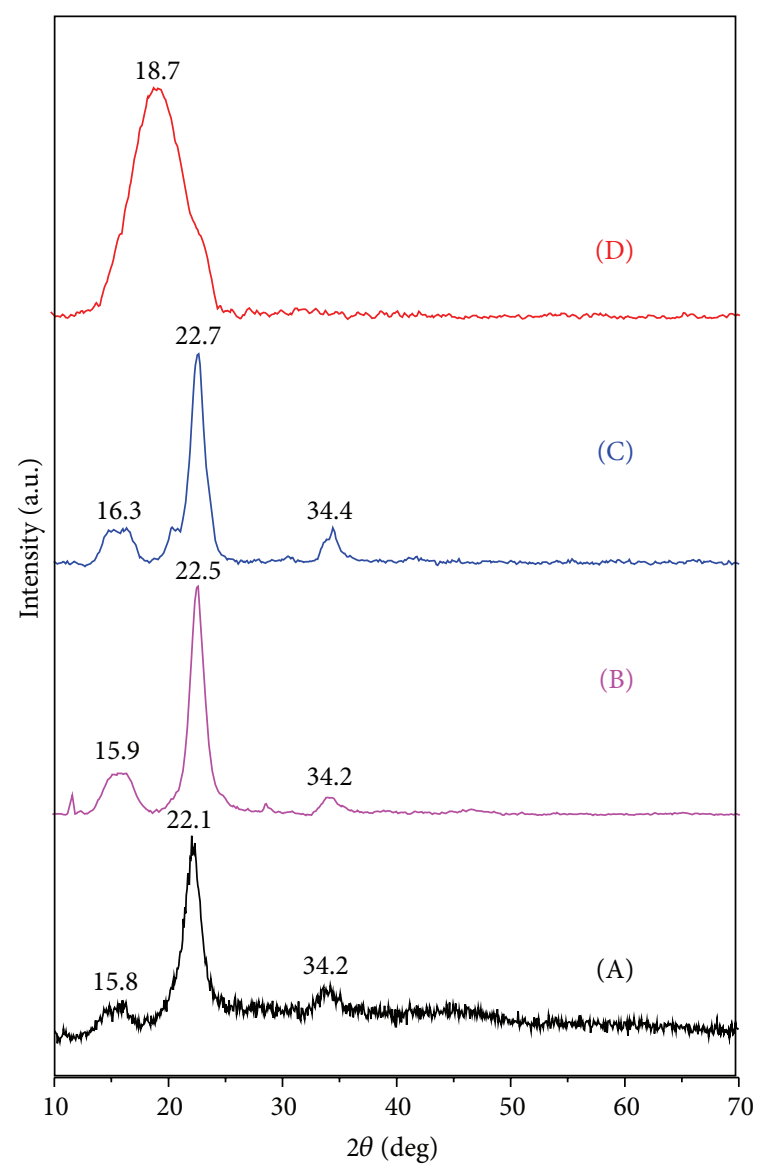

Figure 3: XRD patterns of (A) Cellulose, (B) NC, (C) Co/NCC, and (D) ACDC-Co/NCC.

of ACDC-Co/NCC indicate the modification of the surface of Co/NCC.

3.2.3. SEM Analysis. Figure 4 shows the surface morphology of (a) cellulose, (b) NC, (c) Co/NCC, and (d) ACDCCo/NCC. As seen in Figure 4(a), cellulose has smooth, fibrous, and layered structure, while NC (Figure 4(b)) possesses spindle structure. NC is hydrophilic and behaves like a gel structure. This hydrophilicity of NC may increase the swelling ability and diffusion of solute molecules from aqueous phase. However, Co/NCC shows distinct small gel structures, and these composites are suitable for magnetofection. Also, Co/NCC is irregular, uneven, and rough. The increase in size and swellable structure of ACDC-Co/NCC clearly indicates proper grafting and linking of cyclodextrin molecules to the polymeric chain. The surface of ACDC$\mathrm{Co} / \mathrm{NCC}$ appears to consist of large number of soft folds. Moreover, the folding will provide more surface area for the intake of DNA.

3.2.4. ESR Spectra. ESR spectrum of ACDC-Co/NCC (Figure 5) clearly indicates the inclusion of cobalt magnetic nanoparticles within the polymer matrix. Since the polymer cannot be magnetized under this condition, the peak 


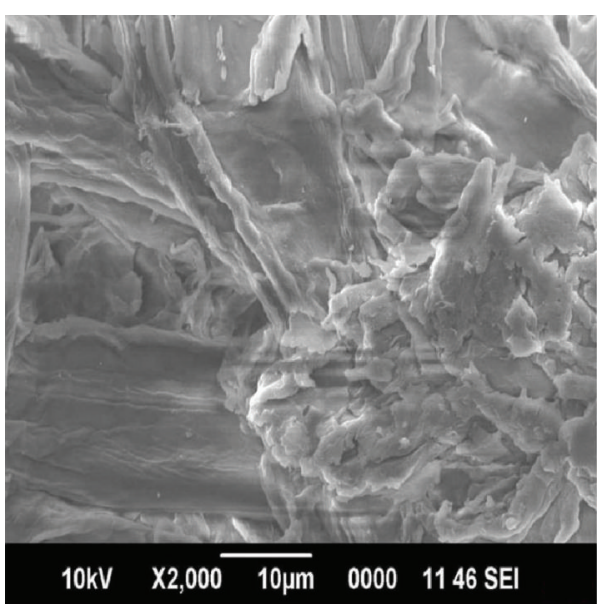

(a)

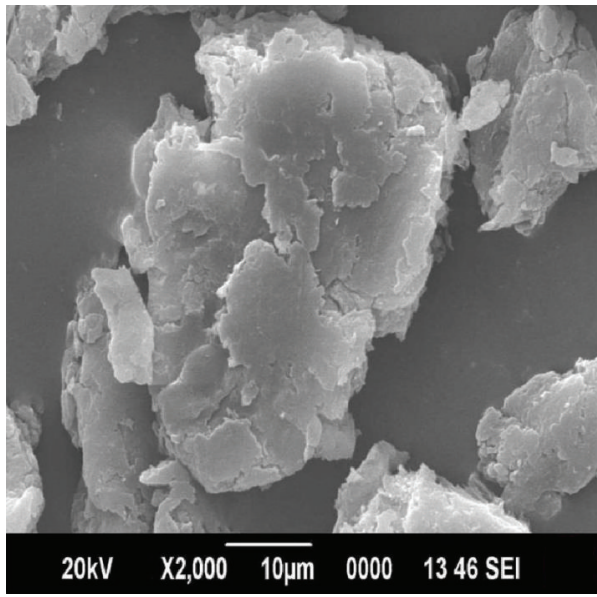

(c)

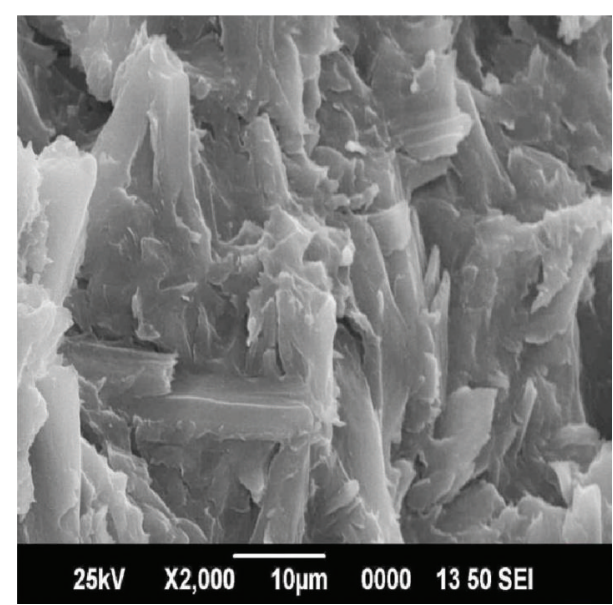

(b)

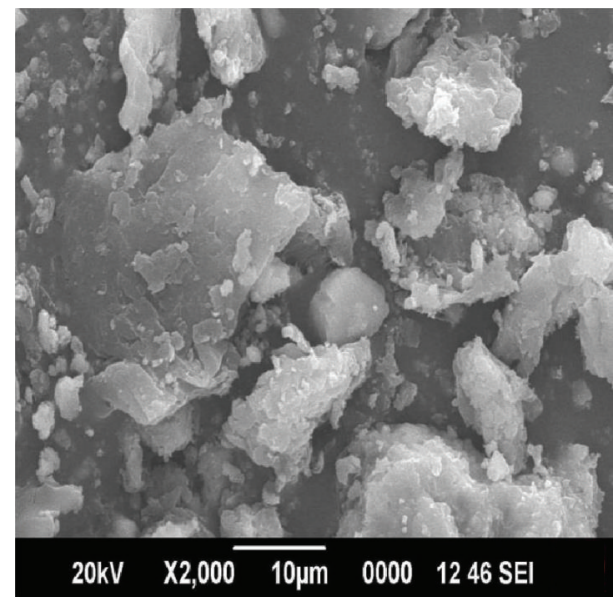

(d)

FIgURE 4: SEM photographs of (a) cellulose, (b) NC, (c) Co/NCC, and (d) ACDC-Co/NCC.

detected in the spectrum may correspond to the magnetic nanoparticles. The $g$-factor can be calculated from the ESR spectrum as

$$
g=\frac{h \nu}{\beta H_{r}}
$$

where $h$ is the Planck constant $\left(6.63 \times 10^{-27} \mathrm{ergs}\right), \beta$ is the universal constant $\left(9.27 \times 10^{-21} \mathrm{erg} / \mathrm{Gs}\right), v$ is the frequency $(9.1$ $\times 10^{9} \mathrm{~Hz}$ ), and $H_{r}$ is the resonance of magnetic field applied (Gs). Here, the $g$-factor was found to be 2.01 for ACDC$\mathrm{Co} / \mathrm{NCC}$ and the magnetic field $\left(H_{r}\right) 3230 \mathrm{Gs}$ was found sufficient to excite all of the dipole moments present in $1.0 \mathrm{~g}$ of the ACDC-Co/NCC. The $H_{r}$ value was changed from $1000 \mathrm{Gs}$ to $20,000 \mathrm{kGs}$ for various applications [43], which implies that the present gene carrier needs less magnetic intensity to target the desired cells using a conventional permanent magnet.

3.3. DNA Inclusion Studies. The inclusion of DNA to the pocket of $\beta$-CD was found to be increased from 19.7 to $84.9 \%$ with increase in the concentration of ACDC-Co/NCC from 1.0 to $6.0 \mu \mathrm{g} /$ well (Figure 6). This is due to the large availability of cyclodextrins which can form inclusion complexes with DNA. In addition to this, the TETA can condense the DNA to form complexes through electrostatic interaction between its protonated amine groups and the negatively charged phosphodiester groups of the DNA. However, the formulations loaded with higher amount of ACDC-Co/NCC ( $>6.0 \mu \mathrm{g} /$ well) exhibited only negligible $\%$ of inclusion.

3.4. The Gene Transfection. The in vitro gene delivery efficiency of the complexes was first evaluated using luciferase at various DNA concentrations. The gene transfection studies (Figure 7) results indicated that the ACDC-Co/NCC exhibited significant transfection performance across the A549 cell line. $88.2 \%$ of the gene was observed to be transfected at high dosage of DNA (1000 ng DNA/well). More than 70\% of the DNA transfection efficiency was achieved even at low dosage of DNA (50 ng DNA/well), indicating the outstanding gene delivery ability of ACDC-Co/NCC. Compared to the leading gene transfecting agent PEI, the ACDC-Co/NCC exhibited significantly improved gene transfection efficiency in A549 cell line. Thus, for the A549 cell line, ACDC-Co/NCC showed 


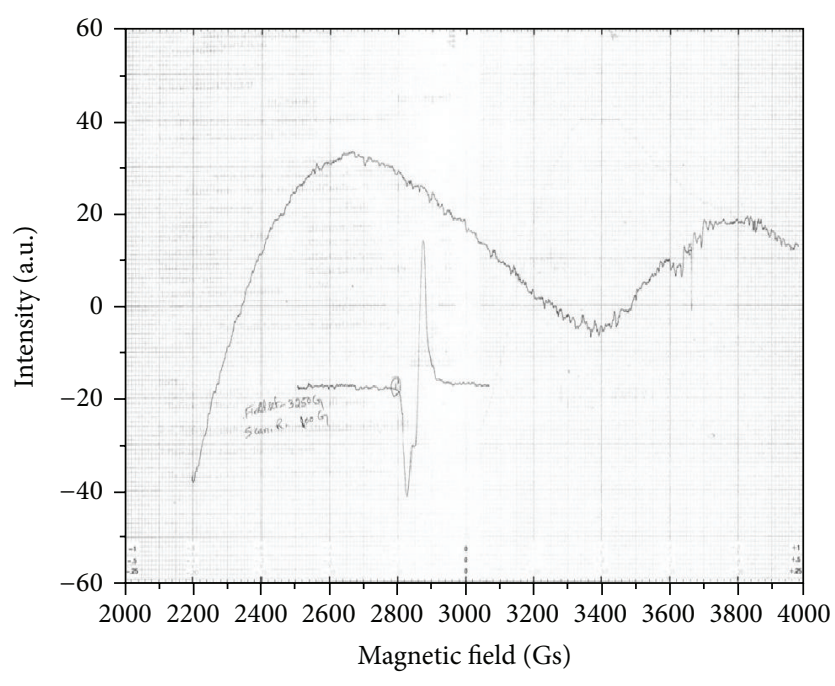

Figure 5: ESR spectrum of ACDC-Co/NCC.

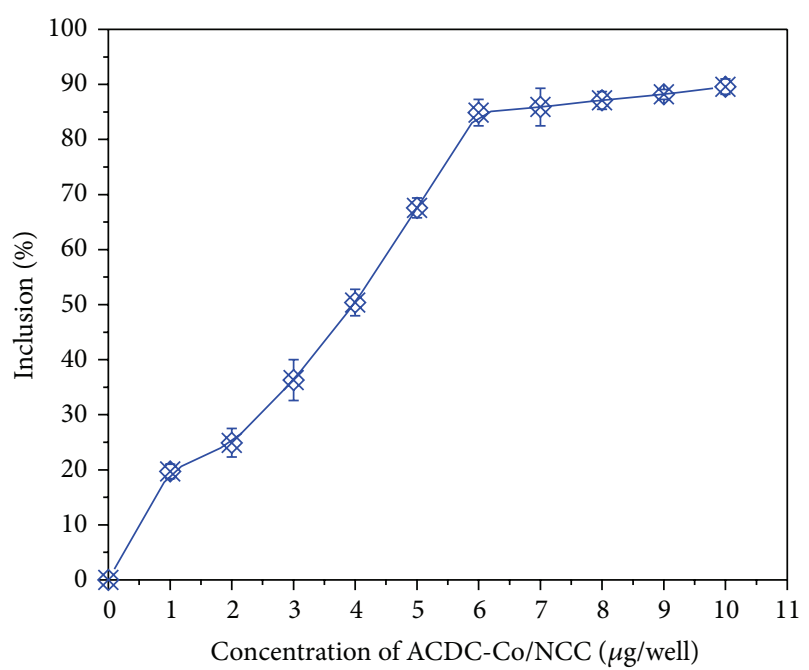

FIgURE 6: Percentage inclusion of DNA with respect to the concentration of ACDC-Co/NCC.

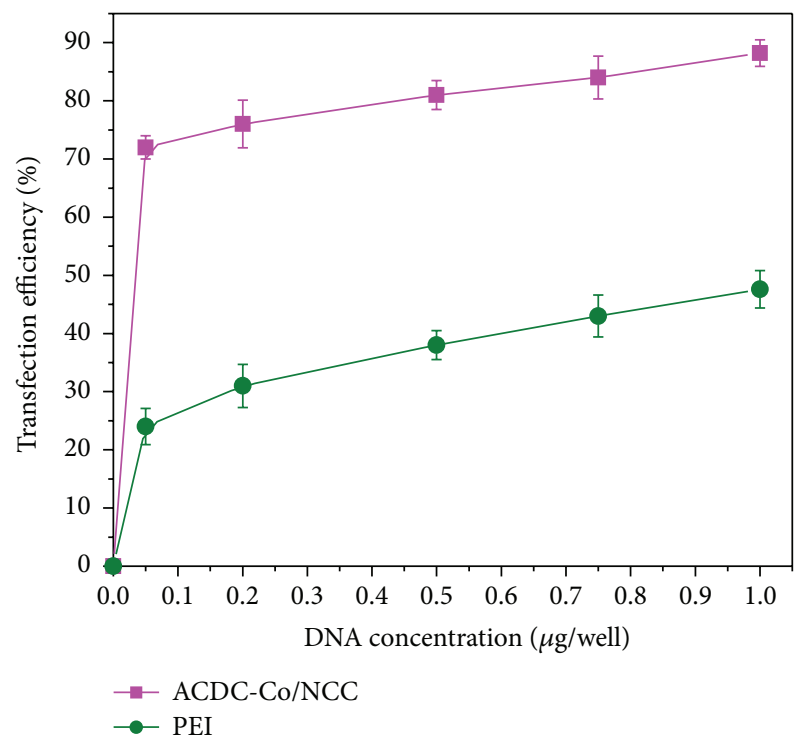

Figure 7: In vitro luciferase expression in A549 cancer cells.

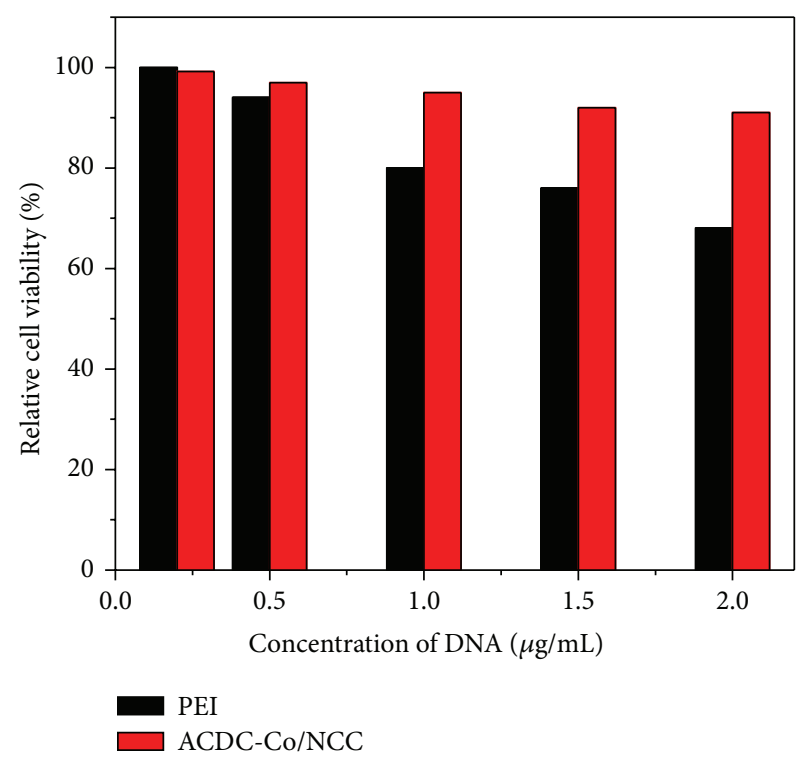

FIgure 8: Relative cell viability of PEI and ACDC-Co/NCC.

higher transfection efficiency and exhibited the highest gene expression.

3.5. Cell Viability. The use of polymeric gene vectors for the safe clinical gene therapy depends on their cytotoxicity. The cytotoxicity of polymer/DNA complexes not only leads to apoptotic cell death but also is associated with the attenuation of gene expression. Figure 8 shows the in vitro MTT assay results of cytotoxicity of the ACDC-Co/NCC and PEI complexes in A549 cancer cells. Cell viability assay results indicated that both the polymer complexes with DNA exhibited minimal toxicity, with the cell cultures maintaining high viability. Among the polymers, ACDC-Co/NCC demonstrated a significantly lower toxicity than that of PEI. It was observed that PEI has a faster increment in toxicity with increase in concentration. Several authors observed this phenomenon during the gene transfection studies $[44,45]$. More than $95 \%$ of DNA transfected cells showed normal viability even in the presence of high dosage of reagent (1000 ng DNA/well). Thus, our novel gene carrier, ACDC-Co/NCC, not only reduced the toxicity but also increased the transgene expression level as well, indicating that ACDC-Co/NCC could be a promising agent for gene delivery.

\section{Conclusions}

The safe and efficient delivery of genes into cells is one of the major objectives in the development of nucleic acid therapeutics. The aim of the present work was to develop a novel gene carrier, aminated $\beta$-cyclodextrin-modified-carboxylated magnetic cobalt/nanocellulose composites (ACDC$\mathrm{Co} / \mathrm{NCC}$ ), for the efficient transfection of genes into tumour cells. The gene carrier was analyzed using FTIR, XRD, SEM, and ESR spectral techniques. DNA condensing ability of ACDC-Co/NCC was measured using ethidium bromide 
assay and was found to be increased with increase in ACDCCo/NCC. The cytotoxicity of ACDC-Co/NCC was observed to be minimal, even at higher concentration, with respect to the model transfecting agent, PEI. $88.2 \%$ of the gene was transfected at high dose of DNA, as indicated by highest luciferase expression. These results suggest that ACDC$\mathrm{Co} / \mathrm{NCC}$ can be used as a reliable carrier for gene delivery.

\section{Conflict of Interests}

The authors declare that there is no conflict of interests regarding the publication of this paper.

\section{Acknowledgments}

The authors thank Department of Chemistry, University of Kerala, for providing laboratory facilities. S. R. Rejeena gratefully acknowledges the financial support from the University Grants Commission (New Delhi) granted Major Research Project (MRP F. no. 37-425/2009 (SR)).

\section{References}

[1] S. Y. Wong, J. M. Pelet, and D. Putnam, "Polymer systems for gene delivery-past, present, and future," Progress in Polymer Science, vol. 32, no. 8-9, pp. 799-837, 2007.

[2] T. J. Anchordoquy, S. D. Allison, M. D. C. Molina, L. G. Girouard, and T. K. Carson, "Physical stabilization of DNAbased therapeutics," Drug Discovery Today, vol. 6, no. 9, pp. 463470, 2001.

[3] R. Bernards and R. A. Weinberg, "A progression puzzle," Nature, vol. 418, no. 6900, p. 823, 2002.

[4] K. Pal, A. K. Banthia, and D. K. Majumdar, "Polymeric hydrogels: characterization and biomedical applications-a mini review," Designed Monomers and Polymers, vol. 12, no. 3, pp. 197220, 2009.

[5] C. Zhang, S. Gao, W. Jiang et al., "Targeted minicircle DNA delivery using folate-poly(ethylene glycol)-polyethylenimine as non-viral vector," Biomaterials, vol. 31, pp. 6075-6086, 2010.

[6] M. Eng and A. Elkordy, "Gene delivery using non-viral vectors (cyclodextrins) with Pluronic-F127 and folic acid," in Proceedings of the 2nd Electronic Conference on Pharmaceutical Sciences, Sciforum Electronic Conferences Series, pp. 1-39, 2012.

[7] J. S. Choi and J. S. Park, "Design elements of polymeric gene carrier," in Biomaterials for Delivery and Targeting of Proteins and Nucleic Acids, R. Mahato, Ed., CRC Press, Boca Raton, Fla, USA, 2005.

[8] L. De Laporte, J. Cruz Rea, and L. D. Shea, "Design of modular non-viral gene therapy vectors," Biomaterials, vol. 27, no. 7, pp. 947-954, 2006.

[9] H. Lv, S. Zhang, B. Wang, S. Cui, and J. Yan, “Toxicity of cationic lipids and cationic polymers in gene delivery," Journal of Controlled Release, vol. 114, no. 1, pp. 100-109, 2006.

[10] D. Putnam, "Polymers for gene delivery across length scales," Nature Materials, vol. 5, no. 6, pp. 439-451, 2006.

[11] M. A. Mintzer and E. E. Simanek, "Nonviral vectors for gene delivery," Chemical Reviews, vol. 109, no. 2, pp. 259-302, 2009.

[12] G. P. Tang, H. Y. Guo, F. Alexis et al., "Low molecular weight polyethylenimines linked by $\beta$-cyclodextrin for gene transfer into the nervous system," Journal of Gene Medicine, vol. 8, no. 6, pp. 736-744, 2006.

[13] V. Burckbuchler, V. Wintgens, C. Leborgne et al., "Development and characterization of new cyclodextrin polymer-based DNA delivery systems," Bioconjugate Chemistry, vol. 19, no. 12, pp. 2311-2320, 2008.

[14] A. Rasheed, A. Kumar, and V. V. N. S. S. Sravanthi, "Cyclodextrins as drug carrier molecule: a review," Scientia Pharmaceutica, vol. 76, no. 4, pp. 567-598, 2008.

[15] S. C. McBain, H. H. P. Yiu, A. El Haj, and J. Dobson, "Polyethyleneimine functionalized iron oxide nanoparticles as agents for DNA delivery and transfection," Journal of Materials Chemistry, vol. 17, no. 24, pp. 2561-2565, 2007.

[16] F. Scherer, M. Anton, U. Schillinger et al., "Magnetofection: enhancing and targeting gene delivery by magnetic force in vitro and in vivo," Gene Therapy, vol. 9, no. 2, pp. 102-109, 2002.

[17] E. M. Umut, Surface Modification of Nanoparticles Used in Biomedical Applications, InTech, 2013.

[18] S. Liang, Y. Wang, C. Zhang et al., "Synthesis of amino-modified magnetite nanoparticles coated with Hepama-1 and radiolabeled with 188Re for bio-magnetically targeted radiotherapy," Journal of Radioanalytical and Nuclear Chemistry, vol. 269, no. 1, pp. 3-7, 2006.

[19] M. A. McDonald and K. L. Watkin, "Investigations into the physicochemical properties of dextran small particulate gadolinium oxide nanoparticles," Academic Radiology, vol. 13, no. 4, pp. 421-427, 2006.

[20] T. Heinze, T. Liebert, B. Heublein, and S. Hornig, "Functional polymers based on dextran," Advances in Polymer Science, vol. 205, no. 1, pp. 199-291, 2006.

[21] T. Maneerung, S. Tokura, and R. Rujiravanit, "Impregnation of silver nanoparticles into bacterial cellulose for antimicrobial wound dressing," Carbohydrate Polymers, vol. 72, no. 1, pp. 4351,2008 .

[22] J. Cai, S. Kimura, M. Wada, and S. Kuga, "Nanoporous cellulose as metal nanoparticles support," Biomacromolecules, vol. 10, no. 1, pp. 87-94, 2009.

[23] E. Lam, K. B. Male, J. H. Chong, A. C. W. Leung, and J. H. T. Luong, "Applications of functionalized and nanoparticlemodified nanocrystalline cellulose," Trends in Biotechnology, vol. 30, no. 5, pp. 283-290, 2012.

[24] J. Vadolas, R. Williamson, and P. A. Ioannou, "Gene therapy for inherited lung disorders: an insight into pulmonary defence," Pulmonary Pharmacology and Therapeutics, vol. 15, no. 1, pp. 6172, 2002.

[25] Z. Mohammadi, M. Abolhassani, F. A. Dorkoosh et al., "Preparation and evaluation of chitosan-DNA-FAP-B nanoparticles as a novel non-viral vector for gene delivery to the lung epithelial cells," International Journal of Pharmaceutics, vol. 409, no. 1-2, pp. 307-313, 2011.

[26] S. W. Gersting, U. Schillinger, J. Lausier et al., "Gene delivery to respiratory epithelial cells by magnetofection," Journal of Gene Medicine, vol. 6, no. 8, pp. 913-922, 2004.

[27] F. Krötz, H.-Y. Sohn, T. Gloe, C. Plank, and U. Pohl, "Magnetofection potentiates gene delivery to cultured endothelial cells," Journal of Vascular Research, vol. 40, no. 5, pp. 425-434, 2003.

[28] S. C. McBain, H. H. P. Yiu, and J. Dobson, "Magnetic nanoparticles for gene and drug delivery," International Journal of Nanomedicine, vol. 3, no. 2, pp. 169-180, 2008.

[29] B. Abdallah, A. Hassan, C. Benoist, D. Goula, J. P. Behr, and B. A. Demeneix, "A powerful nonviral vector for in vivo gene transfer 
into the adult mammalian brain: polyethylenimine," Human Gene Therapy, vol. 7, no. 16, pp. 1947-1954, 1996.

[30] T. S. Anirudhan and S. R. Rejeena, "Adsorption and hydrolytic activity of trypsin on a carboxylate-functionalized cation exchanger prepared from nanocellulose," Journal of Colloid and Interface Science, vol. 381, no. 1, pp. 125-136, 2012.

[31] D. R. Mulinari and M. L. C. P. da Silva, "Adsorption of sulphate ions by modification of sugarcane bagasse cellulose," Carbohydrate Polymers, vol. 74, no. 3, pp. 617-620, 2008.

[32] J. R. Capadona, K. Shanmuganathan, S. Trittschuh, S. Seidel, S. J. Rowan, and C. Weder, "Polymer nanocomposites with nanowhiskers isolated from microcrystalline cellulose," Biomacromolecules, vol. 10, no. 4, pp. 712-716, 2009.

[33] J. Araki, M. Wada, and S. Kuga, "Steric stabilization of a cellulose microcrystal suspension by poly(ethylene glycol) grafting," Langmuir, vol. 17, no. 1, pp. 21-27, 2001.

[34] R. C. Petter, J. S. Salek, C. T. Sikorski, G. Kumaravel, and F.-T. Lin, "Cooperative binding by aggregated mono-6(alkylamino)- $\beta$-cyclodextrins," Journal of the American Chemical Society, vol. 112, no. 10, pp. 3860-3868, 1990.

[35] X. Zhang, Z. Wu, X. Gao et al., "Chitosan bearing pendant cyclodextrin as a carrier for controlled protein release," Carbohydrate Polymers, vol. 77, no. 2, pp. 394-401, 2009.

[36] N. Aoki, M. Nishikawa, and K. Hattori, "Synthesis of chitosan derivatives bearing cyclodextrin and adsorption of $p$ nonylphenol and bisphenol A," Carbohydrate Polymers, vol. 52, no. 3, pp. 219-223, 2003.

[37] I. G. Shibi and T. S. Anirudhan, "Synthesis, characterization, and application as a mercury(II) sorbent of banana stalk (Musa paradisiaca) - polyacrylamide grafted copolymer bearing carboxyl groups," Industrial and Engineering Chemistry Research, vol. 41, no. 22, pp. 5341-5352, 2002.

[38] W.-F. Lai, G.-P. Tang, X. Wang et al., "Cyclodextrin-PEI-Tat polymer as a vector for plasmid DNA delivery to placenta mesenchymal stem cells," BioNanoScience, vol. 1, no. 3, pp. 8996, 2011.

[39] L. V. A. Gurgel, O. K. Júnior, R. P. D. F. Gil, and L. F. Gil, "Adsorption of $\mathrm{Cu}(\mathrm{II}), \mathrm{Cd}(\mathrm{II})$, and $\mathrm{Pb}(\mathrm{II})$ from aqueous single metal solutions by cellulose and mercerized cellulose chemically modified with succinic anhydride," Bioresource Technology, vol. 99, no. 8, pp. 3077-3083, 2008.

[40] A. Alemdar and M. Sain, "Isolation and characterization of nanofibers from agricultural residues-wheat straw and soy hulls," Bioresource Technology, vol. 99, no. 6, pp. 1664-1671, 2008.

[41] K. Das, D. Ray, C. Banerjee et al., "Physicomechanical and thermal properties of jute-nanofiber-reinforced biocopolyester composites," Industrial and Engineering Chemistry Research, vol. 49, no. 6, pp. 2775-2782, 2010.

[42] P. Scherrer, "Bestimmung der Grösse und der inneren Struktur von Kolloidteilchen mittels Röntgenstrahlen," Nachrichten von der Gesellschaft der Wissenschaften zu Gottingen, vol. 26, pp. 98100, 1918.

[43] G. Bayramoğlu, M. Yilmaz, A. Ü. Şenel, and M. Y. Arica, "Preparation of nanofibrous polymer grafted magnetic poly(GMAMMA)-g-MAA beads for immobilization of trypsin via adsorption," Biochemical Engineering Journal, vol. 40, no. 2, pp. 262274, 2008.

[44] D. Fischer, T. Bieber, Y. Li, H.-P. Elsässer, and T. Kissel, "A novel non-viral vector for DNA delivery based on low molecular weight, branched polyethylenimine: effect of molecular weight on transfection efficiency and cytotoxicity," Pharmaceutical Research, vol. 16, no. 8, pp. 1273-1279, 1999.

[45] B. Liang, M.-L. He, Z.-P. Xiao et al., "Synthesis and characterization of folate-PEG-grafted-hyperbranched-PEI for tumortargeted gene delivery," Biochemical and Biophysical Research Communications, vol. 367, no. 4, pp. 874-880, 2008. 

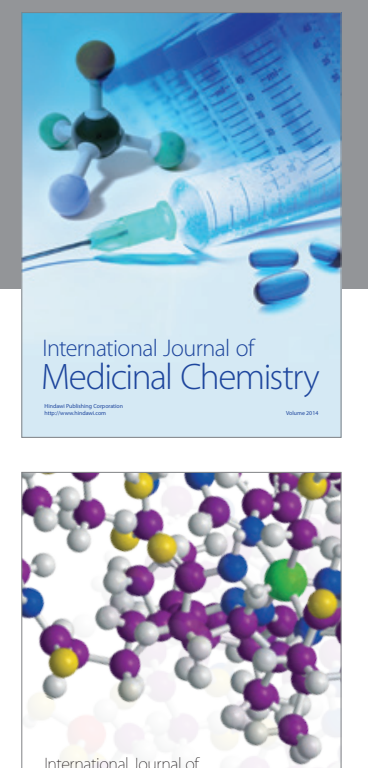

\section{Carbohydrate} Chemistry

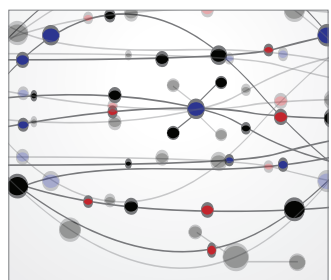

The Scientific World Journal
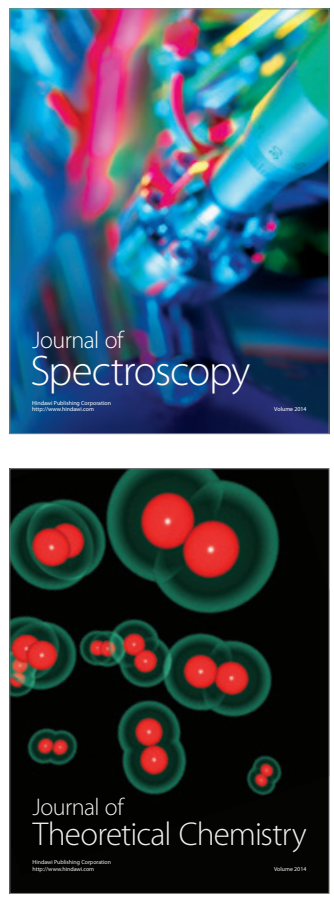
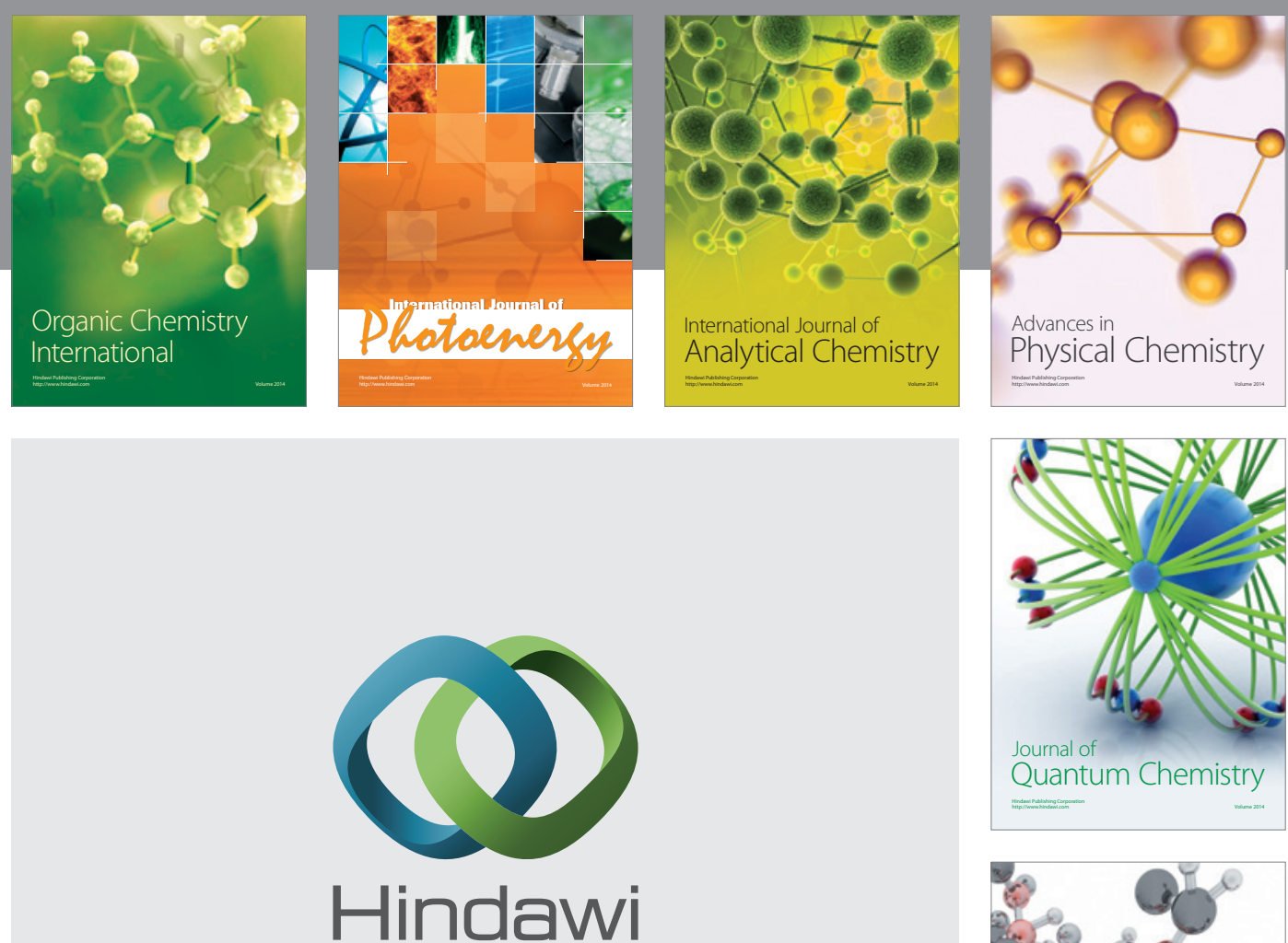

Submit your manuscripts at

http://www.hindawi.com

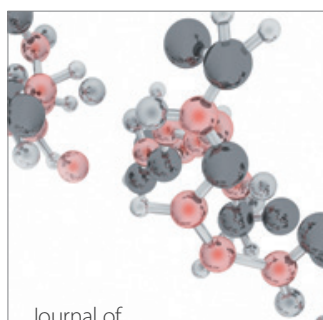

Analytical Methods

in Chemistry

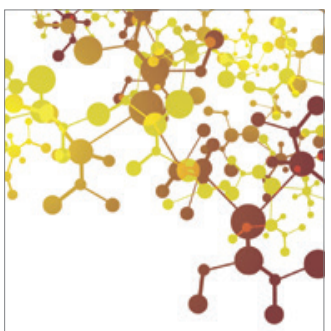

Journal of

Applied Chemistry

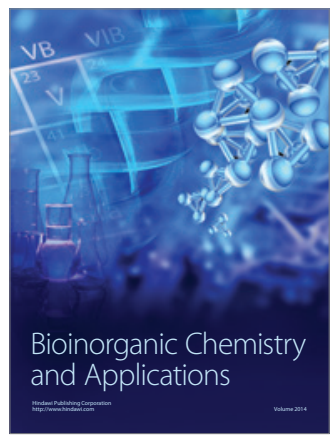

Inorganic Chemistry
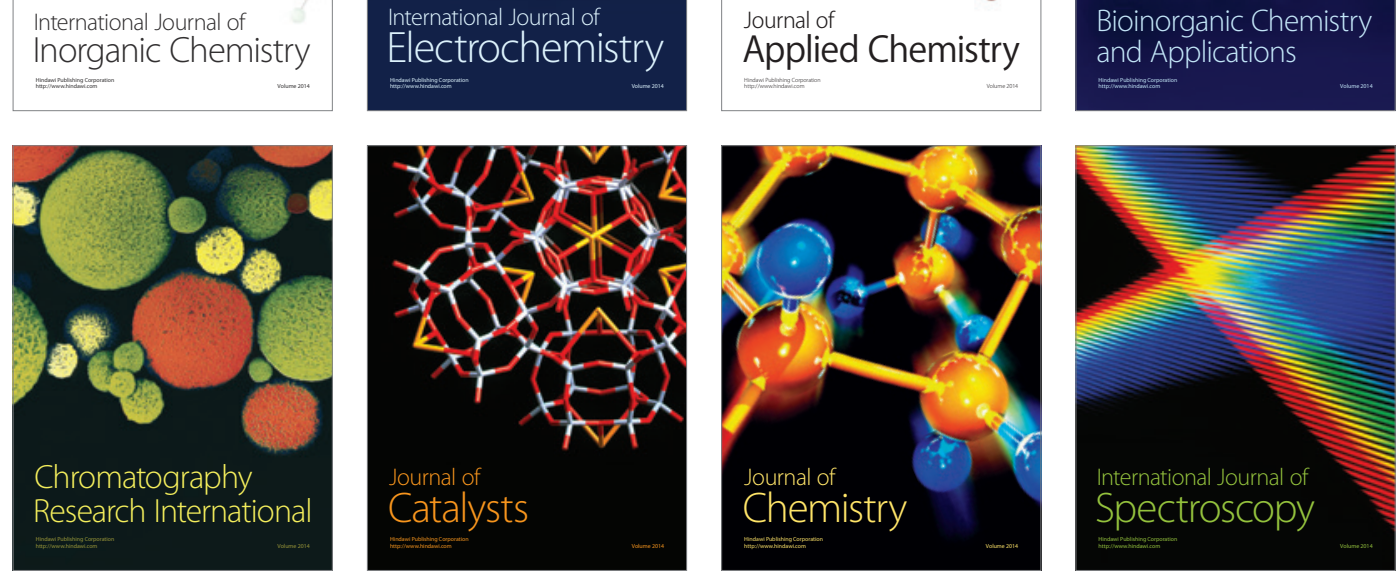